\title{
Conflicts Law: More on Choice-Influencing Considerations
}

\author{
Robert A. Leflar*
}

$\mathrm{D}^{-1}$ URING THE FIRST THIRD of this century choice-of-law rules in the United States were formulated in terms of the conceptual theories which, under Professor Joseph H. Beale, produced the first Conflict of Lawe Restatement ${ }^{1}$ and its rigid allocation of legal control over events to states mechanically selected in accordance with the concepts. Concurrent opposition $^{2}$ was largely negative, directed against Bealian conceptualism rather than in favor of other choice-of-law rules. Rejection of territorialist and substitution of local law starting points ${ }^{3}$ left open the question of what new choices of law should be made. The draftsmen of the second Conflict of Lares Restatement, ${ }^{4}$ with the active assistance of the New York Court of Appeals, ${ }^{5}$ have moved away from the rigid old rules to a new set of somewhat nore flexible but still mechanical rules, now commonly understood as using a "most significant relationship" or "center of gravity" approach. Sinultaneously, Professor Albert Elirenzweig lias been attacking the whole Restatement idea as inherently inappropriate to the conflict of laws field, ${ }^{6}$ while affirmatively proposing non-mechanical rules tied not to conceptuahistic logic but to the practical needs of specific societal situations. ${ }^{7}$ Professor David F. Cavers of Harvard has for years been modestly pressing his argument that the true problem in the cases is often one of a choice between laws, and not necessarily a cloice between jurisdic-

* B.A., 1922, University of Arkansas; LL.B., 1927, S.J.D., 1932, Harvard University; Distinguished Professor of Law, Uuiversity of Arkansas, and Professor of Law, New York University.

1 Restateament, Conflict of Laws (1934). See also Beale, Confuict of Laws (1935).

2 See Lorenzen, Territoriality, Public Policy and the Conflict of Laws, 33 YALE L.J. 736 (1924); Yntema, The Hornbook Method and the Confict of Laws, 37 YaLE L.J. 468 (1928). But see Coox, The Logtcal and Legat Bases of the Conflict of Laws 1-46 (1942).

3 See Cavers, The Two "Local Law" Theories, 63 Harv. L. Rev. 822 (1950).

${ }^{4}$ See Reese, Confilit of Laws and the Restatement Second, 28 Law \& Contemp. Pros. 679 (1963).

5 Babcock v. Jackson, 12 N.Y.2d 473, 191 N.E.2d 279, 240 N.Y.S.2d 743 (1963); Auten v. Auten, 308 N.Y. 155, 124 N.E.2d 99 (1954).

${ }^{6}$ His extensive series of studies usually including the title words "Law and Reason Versus the Restatenent," culminated in Ehrenzweig, The Second Conficts Restatement: A Last Appeal for Its Withdrawal, 113 U. PA. L. REv. 1230 (1965).

7 His treatise, EERENZWEIG, CONFLICT of LAws (1962), in every chapter and section, dwells on the realistic practical aspects of the facts considered, so that the conclusions asserted are designed to further the purpose for which the chosen rules of law exist. See Leflar, Book Review, 16 Stan. L. Rev. 234 (1963). 
tions. ${ }^{8}$ Thus, a choice-making court should take into account the content and function of particular laws as well as their geographical origin. Professor Brainerd Currie developed the companion idea that effectuation of the governmental interests of concerned states ${ }^{9}$ should be a major factor in choice of law decisions. He and others have also pointed out that choice-of-law problems can sometimes be completely avoided by identifying false conflicts ${ }^{\mathbf{1 0}}$ and disregarding them.

In the minds of all the comnientators there has always been a continuing urge to focus upon the true reasons that underlie choice-of-law adjudication: the basic choice-influencing considerations that actually lead, or should lead, the courts to one result or another in particular cases or types of cases. Professors Elliott Cheatham and Willis Reese listed these considerations ("policies") as they saw them, ${ }^{11}$ Hessel Yntema and others summarized them, ${ }^{12}$ Ehrenzweig employed them consistently in all his studies, ${ }^{13}$ and Cavers assumes them throughout his immensely interesting development of proposed "principles of preference"14 for choice-of-law cases. What remained after these studies was a need to reduce the choiceinfluencing considerations to a manageably compact form, a form in which it is realistically practical to make use of them in the day-to-day process of deciding conflicts cases. An effort to do this has produced a tentative list of five major choice-influencing considerations, ${ }^{15}$ within which all or most of the factors that ordinarily affect choice-of-law decisions can be incorporated.

If this tentative summarization is reasonably complete, it can serve as a guide in the actual determination of choice-of-law questions. By using it, courts can replace with statements of real reasons the mechanical rules and circuitously devised approaches which have appeared in the language of conflicts opinions, too often as cover-ups for the real reasons that underlay the decisions. Results in cases will not often be cluanged by setting out in opinions real choice-influencing considerations instead of

8 See Cavers, A Critique of the Choice-of-Law Problem, 47 HARv. L. Rev. 173, 178 (1933); Cavers, Re-Stating the Conficts of Laws: The Chapter on Contracts, XXTH Century Comparative and Confutcts Latw 349, 350 (1961); Cavers, The Chotce-Of-Law Process 9 (1965).

O Currie, Sexected Essats on the Confutct of Latws 165, 183, 188, 341, 621, 727 (1963).

10 See Traynor, Is This Conflict Really Necessary?, 37 Texas I. Rev. 657 (1959).

11 Cheatham and Reese, Choice of the Applicable Law, 52 Coron. I. Rev. 959 (1952).

12 Yntema, The Objectives of Private International Law, 35 CAN. B. Rev. 721 (1957);

Harper, Policy Bases in the Conflict of Lawe: Reflections on Rereading Professor Lorenzen's

Essays, 56 YaLE I. J. 1155 (1947).

13 See note 7 supra.

14 Cavers, The Choice-of-Law Process 114-224 (1965).

15 Leflar, Choice-Influencing Considerations in Conficts Law, 41 N.Y.U.L. Rev. 267 (1966). 
mechanical rules. This is because the real reasons have probably been there all along, whether they were stated or not. Understanding of the decisions, by students, by lawyers, and by other judges will, however, be immeasurably facilitated if the relevant considerations are clearly identified and openly employed. In addition results will occasionally be different.

\section{I}

MAJOR CHOICE INFLUENCING CONSIDERATIONS

A short restatement of the five summarized considerations is given here, followed by an attempt to apply them to the facts of some current cases.

\section{A. Predictability of Results}

Uniformity of results, regardless of forum, has always been a major goal in choice-of-law theory. Achievement of this goal would enable parties entering into a consensual transaction to plan it with reference to a body of law that would give them the results they desired. As a result, their transactions would normally be validated and their justified expectations thus protected. This would further the broad social policies of most forum states by sustaining legal arrangements in which parties have in good faith engaged themselves. At the same time it would discourage "forum shopping."

\section{B. Maintenance of Interstate and International Order}

Both nations and states within a nation are interested in facilitating the orderly legal control of transactions that in any fashion cross their boundary lines. Smooth conduct of affairs between the peoples of different nations is essential to modern civilization; the easy movement of persons and things-free social and economic commerce-between states in a federal nation is essential to the very existence of the federation. There must be a minimum of mutual interference with claims or aspirations to sovereignty. No forum whose concern witl a set of facts is negligible should claim priority for its law over the law of a state which has a clearly superior concern with the facts; nor should any state's choice-of-law system be based upon deliberate across-the-board "forum preference." Encouragement of that measure of interstate and international intercourse which is in keeping with the interests of the forum state and its people has always been a prime function of conflicts law.

\section{Simplification of the Judicial Task}

Courts do not like to do things the hard way if an easier way serves the ends of justice substantially as well. It would be utterly impractical 
for a court hearing a case brought on extrastate facts to apply the whole body of procedural law of the place where the facts occurred, and not much would be gained by doing so. Courts therefore use their own procedural rules. There are, however, some outcome-determinative rules, at times classified as procedural, which are so simple that one state's rule can be used as easily as another's, so that the substance-procedure dichotomy is not sensibly applicable to them. Purely mechanical rules for choice of substantive law are also easy for courts to apply, but other considerations may outweigh simplification of the judicial task where sucli rules are involved. Ease in judicial performance is ordinarily not of first importance among the choice-influencing considerations, but it is important in some choices.

\section{Advancement of the Forum's Governmental Interests}

If a forum state has a genuine concern with the facts in a given case, a concern discoverable from its strongly felt social or legal policy, it is reasonable to expect the state's courts to act in accordance with that concern. This refers to legitimate concerns, not just to the local occurrence of some facts, or to the local existence of some rule of law that could constitutionally be applied to the facts. A state's governmental interests in the cloice-of-law sense need not coincide with its rules of local law, especially if the local rules, whether statutory or judge-made, are old or out of tune with the times. A state's total governmental interest in a case is to be discovered from all the considerations that properly motivate the state in its law-making and law-administering tasks, viewed as of the time when the question is presented. So viewed, the circumstances may slow that the forum is truly interested in applying its own law to a set of facts. If they do show this that conclusion becomes a major choiceinfluencing consideration.

\section{E. Application of the Better Rule of Law}

The better rule of law is the most controversial of the considerations, yet a potent one. If choice of law were purely a jurisdiction-selecting process, with courts first deciding which state's law should govern and checking afterward to see what that state's law was, this consideration would not be present. Everyone knows that this is not what courts do, nor what they should do. Judges know from the beginning between which rules of law, and not just which states, they are choosing. A state's "governmental interest" in a set of facts can be analyzed only by reference to the content of the competing rules of law. Cloice of law is not wholly a choice between laws as distinguished from a choice between jurisdictions, but partly it is. 
A judge's natural feeling that lis own state's law is better than that of other states to some extent explains forum preference. Of course the local law is sometimes not better, and most judges are perfectly capable of realizing this. The inclination of any reasonable court will be to prefer rules of law which make good socio-economic sense for the time when the court speaks, whether they be its own or another state's rules. The law's legitimate concerns with "justice in the individual case," sometimes spoken of as a choice-of-law objective, and with that "protection of justified expectations of the parties" whicl often corresponds with Ehrenzweig's "basic rule of validation," preference for the better rule of law. The preference is objective, not subjective. It has to do with preferred law, not preferred parties. It is "result selective" only in the same sense that in any non-conflicts case a determination of what the law is (presumably the "better law," if there was argument about the law) controls the results of litigation. In conflicts cases, just as in other cases, courts have always taken the content of competing rules into account, but they have too often used characterization, renvoi, multiple-choice rules or the like as manipulative devices to cover up what they were really doing, ${ }^{17}$ when there was no need at all for any cover-up.

II

\section{SOME SPECIFIC APPLICATIONS}

There are areas in which analysis in terms of the five major choiceinfluencing considerations leads almost automatically to the conflicts rules that have already been developed. These considerations almost always demand that land title cases, for example, be governed by situs law. On the other hand in cases involving torts, trusts of personalty, and contracts, choice-of-law rules are traditionally less exact, and application of these considerations to the cases mirrors the inexactness. Analysis in terms of the choice-influencing considerations shows why the old rules are inexact, and at the same time justifies most of the results that have actually been reached under them. Nor is this kind of analysis of specific cases as complicated or difficult a process as might be supposed. It is about as easy as the older and more familiar approaches to conflicts cases. A few recent cases can be used as illustrations. ${ }^{18}$

Case (1). $H$ and $W$, husband and wife who are Spanisl nationals

\footnotetext{
16 Eirenzweig, Conflict of Latws § 175, at 465 (1962).

17 See Morse, Characterization: Shadow or Substance, 49 Corom. L. REv. 1027 (1949).

18 The series of illustrative cases discussed in Leflar, Choice-Influencing Considerations in Conflicts Law, 41 N.Y.U.L. REv. 267, 310-24 (1966), may be taken as a supplement to tho series of cases given here.
} 
and domiciliaries, owned Spanish cash and securities as community property. Between 1919 and the late 1930's they transferred these to a New York bank in a joint custody account, the account agreement providing for joint ownership with survivorship. Under Spanish law this agreement would be void and the property would retain its community character. Under New York law the agreement would be valid. $B$ died first, then $W$ died. $H$ 's estate claimed half the property as community; $W$ 's estate claimed all of it by survivorship. ${ }^{10}$

Merely bringing the cash and securities from Spain to New York clearly did not change the community cliaracter of the spouses' ownership. ${ }^{20}$ The question is the legal effect of the subsequent creation of the joint custody account with the New York bank. That was a New York transaction to which New York law may constitutionally be applied. ${ }^{21}$ But should it be?

It has traditionally been said that nnarital property interests in movables are governed by the law of the spouses' domicile regardless of where the things were acquired or where transactions concerning them may have occurred. ${ }^{22}$ That is a good rule for most purposes because it assures unity of spousal ownership of all their personalty and tends to provide a unified system of distribution wlien one of the spouses dies. If this mechanical rule had been automatically apphed here, $H$ 's estate would have won the cited case, as three of the seven judges of the New York Court of Appeals thouglit it should. But the majority of the judges held that New York's law should govern and that W's estate should prevail. ${ }^{23}$ The followimg analysis of the facts in the light of the relevant choice-influencing considerations appears to sustain the inajority position:

A. Predictability of results at the time the spouses set up their New York custody account was important. They deliberately planned for joint ownership and survivorship in accordance with New York law by a bona

19 The facts are taken from Wyatt v. Fulrath, 38 Misc. 2d 1012, 239 N.Y.S.2d 486 (Sup. Ct. 1963), aff'd. 22 App. Div. 2d 853, 254 N.Y.S.2d 216 (1964), modified and aff'd. 16 N.Y.2d 169, 211 N.E.2d 637, 264 N.Y.S.2d 233 (1965). Jurisdictional issues in the case had earlier been decided in 26 Misc. 2d 554, 207 N.Y.S.2d 511 (Sup. Ct. 1960), rev'd 13 App. Div. 2d 250, 215 N.Y.S.2d 970 (1961).

20 Leflar, Community Property and the Conflict of Laws, 21 CALIF. L. REv. 221 (1933); In re Thornton's Estate, 1 Cal. 2d 1, 33 P.2d 1 (1934). But see Addison v. Addison, 62 Cal. 2d 558, 399 P.2d 897, 43 Cal. Rptr. 97 (1965). For the argument that the authority of Thornton bas been undermined by Addison, see Comment, Marital Property and the Conflict of Laws: The Constitutionality of the "Quasi-Comnunity Property" Legislation, 54 CALF. L. REv. 252, 257-65, 279-80 (1966).

21 Clay v. Sun Ins. Office, Ltd., 377 U.S. 179 (1964). See Leflar, Constitutional Limits on Free Choice of Law, 28 LAw \& Contearp. Prob. 706 (1963).

22 Restatement, Comeutct of Laws \& 290 (1934); Marsh, Marttat Property iv CONFLICT OF LAWS 212 (1952).

23 Wyatt v. Fulrath, 16 N.Y.2d 169, 211 N.E.2d 637, 264 N.Y.S.2d 233 (1965). 
fide transaction which they in good faith expected would produce that result. Their expectation was a reasonable one under the circumstances. The predictable result which they anticipated would be defeated if New York law were not applied.

B. To apply New York's law encourages international transactions of this character; to apply Spain's law would discourage them. They are worthy of encouragement. It is scarcely conceivable that Spain would feel that New York, by applying its law, was impugning Spanish claims to sovereignty in any sense. Neither state's concern with the facts is so clearly superior to the other's as to give rise to any danger of international ill feeling if the other's law is applied.

C. Simplification of the New York court's judicial task is almost irrelevant here. It might be a little easier for a New York court to apply its own rather than Spamish law, but here both rules are simple and the judicial complications under either are insignificant.

D. The forum does not have any major governmental interest that demands advancement here. An advocate, if he tries, can always spell out a local interest in any partly local set of facts. Here he could assert a New York interest in sustaining local banking transactions valid by local law, and the interest in the freedom of spouses to deal with their marital property which induced promulgation of the New York rule permitting transactions such as this one. That the spouses are not New York domiciliaries would scarcely reduce the force of this argument. However, although New York interests exist, they are not strong ones.

E. A New York court can be expected to regard its rule permitting marital freedom in property and contract matters as superior to Spain's rule invalidating such agreements. The Spanish rule, after all, is pretty medieval, although judges might differ and hold strong opinions about this. A majority on any American court would probably be certain that New York's is the better law.

The conclusion from this analysis is clear. Considerations A, B and E all direct us to New York's law as the proper governing law, while considerations $C$ and $D$ do not direct us elsewhere. This is a case in which the values that admittedly support the old mechanical reference to the law of the domicile in the ordinary marital property case are outweighed by other values inherent in the facts of the particular case.

Case (2). $H$ was driving his car, with his wife $W$ and their child $T$ as passengers, through Colorado on the way to their home in Pennsylvania. Due to $H^{\prime} s$ negligence the car was wrecked and $T$ was killed. $W$ sues $H$ in Pennsylvania for $T$ 's wrongful death. Under Colorado law a wife may maintain such an action against her husband, but under Pennsylvamia law she may not. 
A straight characterization approach leading to application of traditional rules would have made this either a torts case, governed by the law of the place of the harmful impact (Colorado), ${ }^{24}$ or a family law case, governed by the law of the family domicile (Pennsylvania) ${ }^{25}$ It is possible that a choice between these two characterizations miglit be motivated by considerations other than those which inhere in pure logic.

Predictability (A) has absolutely no bearing on this problem, because nothing was planned or done with any reference to the wife-husband action rule of either state. If the question had been whether $H$ drove negligently, predictability would have been all-important because both $H$ and others on the same highway had to know what rules of the road applied at the immediate time and place-a question to which only Colorado law could give a definite answer. But that is not the question in our case. Interstate orderliness (B) is not involved here, since no possibility of impairmg claims to sovereign power are presented and interstate automotive movement by citizens will scarcely be affected by a choice of either law. Both state's rules are simple (C), and neither can be niore easily applied by the Pennsylvania court than the other. But Pennsylvania does have a genuine governmental interest (D) in the set of facts. The permanent presence of the spouses as domiciliaries identifies Pennsylvania as the state having the prime interest in their inarital relationship, to which the rules of law in question directly relate. Relationship with a liability insurer and fear of spousal collusions against the insurer also center at the place which is both the forum for the possibly collusive action and the place where the insurance relationship would normally be entered into. Pennsylvania can easily conclude that its total concern with the case is much greater than Colorado's. Moreover, Pennsylvama's rule prohibiting a wife suing her husband for his unintended injuries to their child is not so anachronistic or otherwise contrary to currently accepted social standards (E) as to induce the court to regard Colorado's as the better law.

Analysis in terms of the choice-influencing considerations, with (D) this time being overwhelmingly important, leads to application of Pennsylvania law. That was the result reached by the Pennsylvania court for substantially the same reason. ${ }^{26}$ The court's opinion, after adverting to

24 Gray v. Gray, 87 N.H. 82 , 174 Atl. 508 (1934); Buckeye v. Buckeye, 203 Wis. 248, 234 N.W. 342 (1931).

25 Thompson v. Thompson, 105 N.H. 86, 193 A.2d 439 (1963), overruling Gray v. Gray, supra note 24; Haumschild v. Continental Cas. Co., 7 Wis. 2d 130, 95 N.W.2d 814 (1959), overruling Buckeye v. Buckeye, supra note 24. See Hancock, The Rise and Fall of Buckeye v. Buckeye, 29 U. C표. L. Rev. 237 (1962).

26 McSwain v. McSwain, 420 Pa. 86, 215 A.2d 677 (1966). Cf. Griffith v. United Airlines, 416 Pa. 1, 203 A.2d 796 (1964); Wilcox v. Wilcox, 26 Wis. 2d 617, 133 N.W.2d 408 (1965). 
most of the relevant policy considerations, fell back on a comparison of Pennsylvania's interests with those of Colorado, and held that comparison to be controlling. The inference was that if other choice-influencing considerations had been more significant in relation to the facts, they would have controlled, or would at least have been taken into affirmative account. The opinion very nearly serves as a model for the sort of choice-of-law analysis that this study proposes.

Case (3). In Pennsylvania, $T$, a citizen of Pennsylvania, bought from defendant New York corporation an airhnes ticket for a round-trip from Philadelplia to Puerto Rico. On the return trip the plane carrying $T$ disintegrated in the air above. Maryland and there fell to the ground. A New York action for $T$ 's wrongful death was brought on behalf of his brothers and sisters, his closest surviving relatives. Pennsylvania law allows recovery by surviving brothers and sisters, but Maryland law permits such recovery only by spouses, parents, children or dependents.

New York as forum is in the position of a disinterested third state..$^{27}$ It has no substantial connection with the facts, and application of New York's wrongful death laws would probably be violative of the due process clause in the federal Constitution. ${ }^{28}$ The choice is between the laws of Pennsylvania and of Maryland. The traditional place-of-the-wrong rule for torts would make Maryland law controlling. ${ }^{20} \mathrm{~A}$ contracts cliaracterization $^{30}$ would also be possible. A "center of gravity" or most significant relationships analysis ${ }^{31}$ would presumably lead to application of Pennsylvania's law, ${ }^{32}$ regardless of characterization. Analysis in terms of the relevant choice-influencing considerations would necessarily produce a reference to the law of one of these two states. Hence, it could not greatly affect the result, but it can avoid a mechanical or a disguised basis for the choice and give the real reasons for it.

As in Case (2), predictability (A) has little or no relevancy here. Since the accident was not planned with reference to any state's law, the

27 There are fewer non-mechanical standards to guide choice of law when a disinterested third state is forum than in most other situations. See Currie, The Disinterested Third State, 28 LAw \& Conterap. Prob. 754 (1963).

28 Home Ins. Co. v. Dick, 281 U.S. 397 (1930).

20 Restateanent, Consitct of LAws $\$ 377$ (1934).

30 Levy v. Damiels U-Drive Auto Renting Co., 108 Conn. 333, 143 Atl. 163 (1928); Dyke v. Erie Ry., 45 N.Y. 113 (1871).

31 Babcock v. Jackson, 12 N.Y.2d 473, 191 N.E.2d 279, 240 N.Y.S.2d 743 (1963); Auten v. Auten, 308 N.Y. 155, 124 N.E.2d 99 (1954).

32 That was the result in Long v. Pan Am. World Airways, 16 N.Y.2d 337, 213 N.E.2d 796, 266 N.Y.S.2d 513 (1965), from which case (3) is derived. But see the lower court opinion in Long, 23 App. Div. 2d 386, 260 N.Y.S.2d 750 (1965), overruled by the Court of Appeals, supra, where the majority thought the "center of gravity" test led to application of Maryland law. Cf. Watts v. Pioneer Corn Co., 342 F.2d 617 (7th Cir. 1965); Fabricius v. Horgen, 132 N.W.2d 410 (Iowa 1965). 
choice of forum by one party cannot be seen as an attempt to defeat the other's pre-litigation expectations. Maintenance of interstate order (B) is important in the sense that a disinterested third state as forum especially needs to do a good job of deciding between the competing laws and interests of other states, rather than taking sides unfairly between them, to sustain stability and confidence in our system of federalism. Simplification of the judicial task (C) affords no guidance when the choice is between the laws, both fairly short and plain, of two other states. The forum has no particular governmental interests of its own to be advanced (D) other than its general concern with administering justice well and fairly. In furtherance of this general concern, however, the forum may prefer what it regards as the more enlightened rule of law (E). In this instance, it would be Pennsylvania's since the rule allowing recovery there is a modern one which, incidentally, more nearly corresponds with the civilized rule that prevails in New York. This correspondence could legitimately influence a court. The most relevant considerations here are: (C), which requires the court, for the sake of maintaining good order in a complex federalist system, to weigll carefully the interests of the non-forum states and of the parties with relation to the states in the interstate situation; and, with lesser weight, $(E)$, which may give a preference to what might be regarded as the better law of Pennsylvania. The totahity of considerations leads to a choice of the Pennsylvania rule.

Case (4). $H$ is domiciled in Ontario where he regularly keeps his car and has it insured. $H$ invites $G$, also an Ontario domicihary, to ride with him on a pleasure trip from Ontario into New York and back. While in New York, $B$ drives negligently and injures $G$. Under New York law the standard for the host's liability to his guest is ordinary negligence. By Ontario statute a host is not liable to his guest for mjuries caused by the host's negligent driving. $G$ sues $H$ in New York.

Under the old place-of-the-tort rule, New York law would govern. A contract characterization is scarcely feasible. The center-of-gravity or dominant-contacts approach, to which New York is committed, ${ }^{33}$ apparently would require application of Ontario law, ${ }^{34}$ though it should be noted that the New York court before which the case was brought held that even under this approach New York law should control..$^{35}$ It may

83 See note 31 supra.

84 This would seem to be required by Babcock v. Jackson, 12 N.Y.2d 473, 191 N.E.2d 279, 240 N.Y.S.2d 743 (1963), which held that under the same facts exactly turned around New York law controlled. The facts of Dym v. Gordon, 16 N.Y.2d 120, 209 N.E.2d 792 (1965), were sufficiently different that its holding does not discredit the Babcock v. Jackson rule which $D y m v$. Gordon purported to follow.

35 Kell v. Henderson, 47 Misc. 2d 992, 263 N.Y.S.2d 647 (Sup. Ct.) af'd, - App. Div. $2 d-, 270$ N.Y.S.2d 552 (1965). 
be suspected that some perfectly legitimate choice-influencing considerations not expressly mentioned in the court's opinion helped produce this result. How would they operate if they were brought out into the open?

Predictability (A) again is irrelevant. Auto accidents are seldom planned, and there is no evidence that any aspect of this one was. The host-guest rule does not relate to the manner of driving or the rules of the road. It therefore does not fall within that part of automobile negligence law as to which certainty concerning the governing law is of first importance. Although uncertainty as to what law governed may have encouraged the filing of the suit in New York rather than elsewhere-a fact that has forum-shopping overtones-New York is certainly an appropriate place to try the lawsuit. Neither international order (B) nor ease of judicial administration (C) has much bearing on the case. Automotive intercourse between the United States and Canada, or between New York and Ontario, will not be discouraged by apphication of one state's rule or the other's, nor will either sovereign be offended. No international discomfiture will ensue. And the forum will have no administrative difficulty in applying either rule.

The New York forum does have some governmental interest (D) in the case, however. Its interest is not the intensely practical one which relates to supervision and safety of the state's highways, since the rule in question, unlike rules of the road and definitions of negligence, does not bear upon vehicle operation as such. A governmental interest connected with any particular rule of law has to do with the operative effect of that rule. In this instance the relevant effect is the bearing of the New York negligence rule on the duty of a host to a guest, and the danger of collusion between host and guest to defraud the host's insurer. New York's interest in applying its own law rather than Ontario's on these issues is based primarily on its status as a justice-administering state. In that status it is strongly concerned with seeing that persons who come into New York courts to litigate facts with substantial New York connection have their cases determined according to rules consistent with New York's concepts of justice, or at least not: inconsistent with them. That will be as true for non-domiciliary litigants as for domiciliaries. ${ }^{30}$ This interest will not mamifest itself clearly if the out-of-state rule does not run contrary to some strong socio-legal policy of the forum, but it will become a major consideration if there is such a strong opposing local policy.

That consideration leads to (E), preference for what is regarded as the better rule of law. In this instance New York has such a preference,

${ }^{36}$ Cf. Weintraub, An Inquiry into the Utility of "Domicile" as a Concept in Conflicts Analysis, 63 MICH. L. Rev. 961 (1965). 
and it is a vigorous one. New York is one of the states that never succumbed to the insurance lobby's campaign for host-guest statutes, and on the whole regards such enactments with justified distaste. Many of the states that acquired these acts in the 1930's are coming to share New York's attitude. ${ }^{37}$ The hitchiker era that produced them is past, and current feeling is that they are both unfair to guests and contrary to the enterprise liability, spread-the-loss concept that prevails in the automobile tort area today. Moreover, the Ontario act, barring as it does all guest recovery even for gross negligence, may well be regarded as the most undesirable of all the enactments. A New York court would probably think that its negligence rule makes better socio-economic-legal sense than Ontario's host-guest statute, and that the functions of law in society would accordingly be better served by applying New York's rule. The combination of considerations (D) and (E), therefore, seems to call for the application of New York law.

Case (5). $P$, a Delaware corporation, operates a hicensed gambling casino in Puerto Rico. $G$, a New York domiciliary, gambled at $P$ 's casino. He there gave $P$ a check on $G$ 's New York bank account for 3,000 dollars to pay for chips which he then lost. $G$ stopped payment of the check before it was cashed. Under Puerto Rican law the check constituted a valid contractual obligation; under New York law it was an illegal gaming contract. $P$ sues $G$ in New York for the amount of the check.

If the law of the place of making governed, ${ }^{38}$ the contract would be valid under Puerto Rican law. If place of performance governed, ${ }^{39}$ the law of New York, the place of payment of the check, would invalidate it. Assuming good faith on both sides in issuance and acceptance of the clieck and an intention that the law of Puerto Rico should govern, an intention-of-the-parties rule would require reference to Puerto Rican law. ${ }^{40}$ The same result would follow if Ehrenzweig's "basic rule of validation"41 were employed. Under a "center of gravity" or most-significantrelationship approach, ${ }^{42}$ it would be difficult to predict whether the Puerto Rican gaming parts of the transaction, or the New York domicile plus the check being drawn on and payable at a New York Bank, would be deemed to give rise to the dominant contacts. Actually, the New York Court of Appeals ignored that question, assumed that Puerto Rico's law

37 See Pedrick, Taken for a Ride: The Automobile Guest and Assumption of Risk, 22

LA. I. REv. 90 (1961); Comment, The Ohio Guest Statute, 22 OHro ST. L.J. 629 (1961).

382 BeaLe, CoNELICT of Laws $\$ 332.4$ (1935).

$39 \mathrm{Id}$. at $\S 332.3$.

40 See Goodrich, Conflict of Laws 213 (Scoles ed. 1964).

11 Ehrenzweig, Confuct of Laws $\S 175$, at 465 (1962).

42 Compare Haag v. Barnes; 9 N.Y.2d 554, 175 N.E.2d 441, 216 N.Y.S.2d 65 (1961), with Auten v. Auten, 308 N.Y. 155, 124 N.E.2d 99 (1954). 
governed so that the check was valid, and devoted its opinion to the separate question whether any strong New York public policy barred enforcement of the valid contract. The majority permitted enforcement. ${ }^{48}$ Nevertheless the validity question is an interesting one.

Predictability (A) is always important in contracts cases. Parties contracting in good faith presumably desire a valid contract. They want their contract governed by a law that will protect the expectations under which they act. Public policy generally favors sustaining transactions that are not anti-social. Maintenance of good relations between New York and Puerto Rico as states (B) also favors recognition of the Puerto Rican claim. This consideration is more important here than it would be in most cases between states of the United States, or between American states and a foreign nation, because of Puerto Rico's special relationship to this country and her extraordinary efforts, with state-side encouragement, to build up her economy and political status. Simplification of the forum court's judicial task (C) is practically irrelevant since both rules of law are clear and easy to apply to the facts. New York has no strong governmental interest (D) in its anti-gambling rules as applied to policed gambling occurring in and regulated by another responsible jurisdiction, particularly since New York allows other forms of policed gambling (parimutuel betting at race tracks and church bingo games) within its own territory. The degree of New York's interest is not appreciably affected by the involvement of a New York domiciliary and payment which was to be made out of his New York bank account. These facts are only incidental to the larger issues in the case. Finally, New York probably has no strong feehing about its rule being any better, as law, than Puerto Rico's. Some states (Kansas for example) might have such a feeling, but New York is more placid. The weight of considerations (A) and (B), plus the umimportance of (C), (D) and (E), make the New York decision sustaining the contract a proper one.

Case (6). $P$, an American citizen domiciled in New York, was in Brazil on business. There he bougltt a ticket for an air fiight, wholly in Brazil, on defendant Brazilian airline. $P$ was injured as a result of the pilot's negligence in landing at a Brazilian airport. Under Brazilian law the maximum allowable recovery is 100,000 cruzeiros, now worth about 140 dollars in United States money. New York law sets no top limit on recoveries. $P$ sues in New York, where defendant Brazilian airline is effectively brought into court and defends on the merits.

43 Intercontinental Hotels Corp. (P.R.) v. Golden, 15 N.Y.2d 9, 203 N.E.2d 210, 254 N.Y.S.2d 257 (1964). To fill in the facts, see reports of the case in the lower courts, 36 Misc. 2d 786, 233 N.Y.S.2d 96 (Sup. Ct. 1962), rev'd 18 App. Div. 2d 45, 238 N.Y.S.2d 33 (1963), in turn reversed by the Court of Appeals. 
Measure of damages questions have sometimes been characterized as procedural and hence governed by the law of the forum. ${ }^{44} \mathrm{~A}$ more realistic view, however, acknowledges that the difference between 140 dollars and 14,000 dollars is substantive. ${ }^{45}$ Not all substantive issues arising from a particular set of facts need necessarily be governed by the same law, but most courts would agree that forum law as such ought not to control. ${ }^{48}$ The choice-influencing considerations ought to be employed with specific reference to the facts of the particular case.

Though predictability (A) as to governing law has no relevance to the unplanned air crash itself, it does have bearing on amounts payable under the airline's liability insurance. Since the airline operated wholly in Brazil, whatever insurance it carried, and its economic planning with reference to amounts of hability, were surely related to Brazil's law. And forumshopping by plaintiffs would be definitely encouraged if law other than Brazil's could control measure of daniages.

International relationships (B) are very important in this case. Brazil's rule apparently represents a deliberate national policy to assist an infant industry, important to the nation's growth, by holding down its operating costs. This comes close to the character of a sovereign concern in a friendly nation, with which any state slould be reluctant to interfere.

Simplification of the judicial task (C) is the consideration that normally justifies a forum court in applying its own procedural rules regardless of where the facts arose. Applying Brazilian procedure in a New York trial would be burdensome, inefficient, and impossible. Yet Brazil's rule of daniages can be easily applied. The reasons for the substanceprocedure dichotomy have no bearing on the damages rule. And as to New York's governmental interest in the case (D), $P$ 's domicile in the state is the only connecting factor on which it could be grounded. A state, of course, has some concern with the welfare of its domiciliaries, but that concern in itself is minor when it relates to the measure of damages for extrastate injuries on such facts as these. Domicile as a choice-influencing factor is currently decreasing in importance, ${ }^{47}$ except as it affects considerations other than governmental interest. A New York court would without any doubt feel that its damages rule is, as law, decidedly superior to Brazil's (E), but this consideration declines near to zero in importance

44 Kilberg v. Northeast Airlines, Inc., 9 N.Y.2d 34, 172 N.E.2d 526, 211 N.Y.S.2d 133 (1961). This result was held to be constitutionally permissible in Pearson v. Northeast Airlines, Inc., 309 F.2d 553 (2d Cir. 1962), cert. denied, 372 U.S. 912 (1963).

45 See Leflar, Conflict of Laws \& 65 (1959).

$40 \mathrm{New}$ York now agrees, and has in effect withdrawn from the view taken in that part of the Kilberg case, supra note 44. Davenport v. Webb, 11 N.Y.2d 392, 183 N.E.2d 902, 230 N.Y.S.2d 17 (1962).

47 See note 36 supra. 
compared to considerations (A) and (B) on these facts. The forum court probably will not really prefer Brazil's law, but the balance of considerations will nevertheless impel it to apply the disliked law. ${ }^{48}$

\section{CONCLUSION}

In the cases just analyzed, there was room for difference of opinion as to the significance of the various considerations in relation to the facts, as to the factors which give meaning to particular considerations, and as to the weight to be assigned them in the ultimate judicial process that produces decisions. In each of the six cases, analysis in terms of the relevant five major choice-influencing considerations supported the results arrived at, sometimes assertedly for other reasons, by the courts from whose opinions the six illustrations were taken. In some of the cases analysis based on these considerations might, however, have produced dissents, and perhaps majority opinions in some courts, by reason of a different weighing of their values. Only a mechanical rule, as the law of the place of making always governs a contract, can even in theory avoid judicial difference of opinion. We expect dissents and opposing decisions. Furthermore, in conflicts cases, the opposing views have quite often been based, at bottoin, on divergent weiglits given by the judges to the policy values that underlie the supposed choice-of-law rules.

An approach which looks directly and specifically to the relevant choice-influencing considerations, rather than one looking to some formula supposedly derived from the considerations by earlier alchemists, has the virtue of enabling the judges to concentrate on all of the real values, as they see thein, that are present in their case. It permits them to recognize values that may not have been present in prior cases with superficially similar facts. Particularized employment of the considerations will not change results $\mathrm{m}$ cases, such as those presenting land title questions, for which the considerations have already produced accepted rules, although it will leave room for variation from the norn in exceptional situations even in those areas. However, the direct approach should lead courts and lawyers away from a mechanical examination of psuedo-rules, sub-rules, and exceptions to non-existent rules; away from ritualized talk about deduced formulae and manipulative ginmicks treated as if they had reality; and away from the contrived artificialities of analytical logic masquerading as conflicts law, into a fairly simple process of histing and systematically taking into account the policy values that are relevant to choice-of-law decision.

48 Ciprari v. Servicos Aereos Cruzeiro, 245 F. Supp. 819 (S.D. N.Y. 1965), aff'd, 359 F.2d 855 (2d Cir. 1966). See also Tramontana v. S.A. Empresa de Viacao Aerea Rio Grandense, 350 F.2d 468 (D.C. Cir. 1965). Cf. Cherokee Laboratories, Inc. v. Rogers, 398 P.2d 520 (Okla. 1965) (considerations not considered). 